\title{
The Significance of Plant Variety Protection System: A Sri Lankan Perspective
}

\author{
Pathiraja P.M.A.S.
}

\author{
Department of Legal Studies, The Open University of Sri Lanka, Sri Lanka \\ anushapathiraja13@gmail.com
}

\begin{abstract}
Sri Lanka has been identified as a rich biodiversity hotspot of endemic species among flora and fauna in the world. Currently, its biodiversity is under threat due to the actions of bio piracy. In the domestic scenario, the importance of strengthening the protection for plant varieties has been highlighted through a series of increasing incidents regarding the bio piracy. Sri Lanka has enacted some legislation to protect plant varieties which provide only the physical protection of the plant resources. The lack of proper legal protection for the genetic resources of plants is a great weakness of the existing legal framework of Sri Lanka. The importance of protecting plant varieties through intellectual property rights are addressed by the Agreement on Trade Related Aspects of Intellectual property rights (TRIPS). Furthermore, the International Convention for the Protection of New Varieties of Plants (UPOV) aims to encourage the development of new varieties of plants and provides some standards and guidelines for such protection. Sri Lanka being a member of WTO is bound to implement TRIPS agreement in its legal framework. Sri Lanka enacted the Intellectual Property Act No 36 of 2003 in order to fulfill its commitment under TRIPS. One of the requirements of TRIPS Article 27.3(b) is that plant varieties should be protected either by patents or by an effective sui generis system or some combination thereof. The Intellectual Property Act specifically excludes plants and animals from patentability within its application. Hence, it is important to provide protection through other mechanism. Like many developing countries Sri Lanka has opted for s sui generis system for the protection of plant varieties and taken steps by introducing a Bill on Plant Variety Protection (Breeder's Rights) which was drafted in 2001 to comply with the requirements of TRIPS Article 27. Sixteen years later, there is still no progress regarding it. Therefore this paper discusses the problem of protecting plant varieties in Sri Lanka and expects to make suggestions to strengthen the drafted Bill on plant variety protection. This is a qualitative research based on literature review and mainly carried out by reference of primary and secondary sources such as Statutes, international treaties, academic writings and e-sources. The comparative analysis of successful legal position in India has been used in reaching the conclusion.
\end{abstract}

Keywords: Patent, Plant variety protection, Sri Lanka, TRIPS, India 